Ukrainian tailors in the organization and activities of the Stauropean Brotherhood in Lviv (late $16^{\text {th }}-$ early $17^{\text {th }}$ centuries)]. Proceedings of the Shkola Lvivskoho stavropihiiskoho bratstva: tradytsii dukhovnoi osvity u Lvovi. Tezy dopovidei ta povidomlennia naukovoi konferentsii molodykh vchenykh (Lviv, 20-22 hrudnia 2016 r.). Lviv. P. 46-48.

5. Tsentralnyi derzhavnyi istorychnyi arkhiv Ukrainy, m. Lviv. F. 52. Op. 1. Spr. 332. 14 ark.

\title{
SOVIETIZATION OF ROKYTNE (RIVNE REGION) DURING 1939-1941
}

\section{Liudmyla Rudnytska ${ }^{1}$}

DOI: https://doi.org/10.30525/978-9934-26-002-5-22

During the period of Second World War urbanization level underwent significant changes, particularly, annexed ones because of the Red Army's occupation of western Ukraine in September 1939. The installation of Soviet power in Volhynia took place according to the classical scheme. On the seventeenth of September, Polish police and army formations along with the Polish families who actively participated in the social life of the village [8, p. 237-245].

The eastern USSR Soviet and party officials were to be the basis of the state apparatus of the newly annexed lands [4, p. 44-76]. The mayor of Rokytne Bratsky decided to cooperate voluntarily with the new government, namely taking the position of a civil servant in the municipal committee [8, p. 243-245]. Taras Bulba-Borovets, the owner of a stone quarry, worked as a lumber mill worker with the advent of Soviet power [11, p. 67-68]. A large proportion of the Jewish population took managerial and administrative positions in Rokytne village [3]. Thus, began the first stage of Sovietization of Rokytne village and Western Ukrainian lands as well, namely, temporary local authorities were created, subordinating to the commanders of the Red Army [6, p. 75-81] in accordance with the Resolution of the Central Committee of the CPSU (b) of the first of October, 1939.

Legal registration of the Western Ukrainian lands annexation became possible after the People's Assembly of Western Ukraine on twenty-sixth-twenty-eighth of October in 1939 in Lviv. The city was to be considered the place where the Declaration on the reunification of lands was adopted [5, p. 41-48]. Mushka

\footnotetext{
${ }^{1}$ Borys Grinchenko Kyiv University, Ukraine European University, Ukraine
} 
Shuster, the wife of one of the local representatives of merchants, Yehoshua Shuster, was delegated from Rokytne village (town) [8, p. 253].

The decree of the Presidium of the Supreme Soviet of the USSR dated the fourth of December, 1939 officially formed the Rivne region with its centre in Rivne town. It included five former counties [9, p. 62]. At the same time, there was a unification of the newly annexed territories. In 1940, the four settlements of Rivne region were granted the status of urban-type settlements, namely Rokytne, Mizoch, Klesiv and Klevan. The region encompassed thirty districts and eight hundred fifty nine village councils, with unstable, constantly changing number [10, p. 196-197].

The newly annexed lands were implemented (adjusted) by means of classical scheme, namely nationalization, collectivization, industrialization, state monopoly as well. The Red Army introduced the process of nationalization, ensured the land, production, housing and material resources, and facilitated the task of further socio-economic reforms. Eight-hour working day and a seven-day working week, the prohibition on the unauthorized leaving of workers of their working places from enterprises, and institutions led to a wave of discontent among the local Jewish population [2, p. 48-57] of Rokytny village. The last ones were forced to work on Shabbat, and this in its turn, led to a reduction of the number of the synagogue parishioners. Notwithstanding this, the Soviet government did not close the Jewish synagogue [8, p. 237-242]. The Polish Christmas celebration process was almost similar to previous years [7, p. 6-7].

Industrial and socio-cultural entities of Rokytne village (town) were subject to nationalization, namely hotels, swimming pools, baths, hospitals, pharmacies, dental offices and educational institutions, as well as cinemas, theatres, stadiums, libraries, restaurants, shops, canteens, warehouses [2, p. 157], and Rosenberg Palace. The Polish Officers' Club, located near the glass factory, served as a youth club. The new Soviet library, the former Jewish one, located at Mitskevich Street, was opened in February 1940. There were stored books printed and edited in the Soviet Union. However, there was a selection in Yiddish as well [8, p. 243-245].

A number of drastic measures of the new government were aimed at the searching of «enemies» [2, p. 48-52], who were arrested and deported to Siberia. The pharmacist N. Solzman and teacher M. Handelman were the first detainees in the Sarny prison, dated September 28, 1939 [8, p. 237-242]. The members (participants) of the Soviet-Polish war of 1920, servicemen, Polish soldiers who resisted the German and Soviet invasions of 1939, as well as the families of fallen soldiers were captured by NKVD officials [7, p. 7]. Until 1941, Lieutenant Bobrov was the head of NKVD. The Rokytne NKVD department was located at Mitskievich Street, the pre-trial detention centre 
was not far from the residential complex of the glass factory, in the house of L. Grishpan. The «criminals» after interrogation were sent to prison from the starting place.

Meanwhile Social infrastructure played the leading position. The reformation of town streets, namely Sobesky Street was replaced by Mitskevich one, Tsentralna by Kahanovych, Pilsudskyi by Proletarska, Kostyshko by Dzerzhinsky as well [1, p. 1-20]. In early September 1939, heavy Soviet locomotives with soldiers and equipment arrived at the RokytneVolynske railway station. Restoration (renovation) of the rail link has been implemented. Only special permit document gave the right to leave the town. Locality transportation was reactivated, as well as food supplies [8, p. 237].

The Sovietization played the colossal positive role associated primarily with the social sphere, namely free of charge education and medicine as well [2, p. 48-52]. In Rokytne there was started up a hospital with forty beds, and at the glass factory there was a kindergarten. Tarbut School was reorganized into a Seventh-Grade Elementary School. The graduates (school leavers) were forced to continue their education in a Secondary, Ukrainian-Language School, which was located in a new building, with additional eighth grade for Jewish pupils, with Russian-language-form-education, despite the lack of teachers [8, p. 87-110].

Thus, the first arrival of Soviet power led to administrative and territorial changes as well, especially the loss of urban status of Rokytne village, and the wave of nationalization, namely glassworks, banks, transport, land, forced property expropriation, repression and deportation were the origin cause of a sharp decreasing in living standards and social cultural degradation as well.

\section{References:}

1. Arkhiv Rokytnivs'koho sklianoho zavodu [Archive of Rokytne Glass Factory]. Bukhhalters'kyj oblik sklozavodu za 1944 rik [Accounting of the glass factory during 1944], 257 ark.

2. Borisenok E. Yu., Petrovskaya O. V. (2011). Zapadnaya Belorussiya i Zapadnaya Ukraina v 1939-1941 gg.: lyudi, sobytiya, dokumenty [Western Belarus and Western Ukraine in 1939-1941: people, events, documents]. SPb.: Aletejya, $424 \mathrm{~s}$. (in Russian)

3. Dytkowski Jerzy. Rokitno Wołyńskie 1920-1944. Pamiętnik Jerzego Dytkowskiego. [Rokytne-Volyns'ke 1920-1944. Diary of Jerzy Dietkovsky]. Available at: http://wolyn.freehost.pl/wspomnienia/dytkowski_rokitno.html

4. Filippov S.G. (1997). Deyatel'nost' organov VKP(b) v zapadnyx oblastyax Ukrainy i Belorussii v 1939-1941 g. [The activities of the bodies of the CPSU (b) in the western regions of Ukraine and Belarus in 1939-1941]. Repressii protiv polyakov i pol'skix grazhdan: istoricheskie sborniki «Memoriala» [Repressions against Poles and Polish Citizens: Historical Collections of «Memorial»]. M.: Zven'ya, vyp. 1, s. 44-76. (in Russian) 
5. Kul'chickij V.S. (1979). Istoricheskie resheniya Narodnogo sobraniya Zapadnoj Ukrainy [Historical decisions of the People's Assembly of Western Ukraine]. Problemy pravovedeniya: Respublikanskij mezhvedomstvennyj nauchnyj sbornik [Problems of Jurisprudence: Republican Interdepartmental Scientific Collection], Ministerstvo vysshego i srednego special'nogo obrazovaniya USSR; Kievskij gosudarstvennyj universitet im. T.G. Shevchenko, Kiev: Vishha shkola, vypusk 40, s. 41-48. (in Russian)

6. Levyts'ka O. (2008). Metody radianizatsii Zakhidnoi Ukrainy u 1939-1940 rr.: Na osnovi arkhivnykh dokumentiv Stanislavs'koi oblasti [Methods of sovetization of the Western Ukraine in 1939-1940: On the basis of archival documents of the Stanislav region]. Skhid: Analitychno-informatsijnyj zhurnal [East: Analytical and information magazine], N7. S. 75-81. (in Ukrainian)

7. Pląskowski Tadeusz. (2001). W poszukiwaniu sensu życia. [In search of the meaning of life]. Moje Wojenne Dzieciństwo [My War Childhood]. Tom 7, Praca zbiorowa, 212 s. Available at: http://www.mojewojennedziecinstwo.pl/pdf/ 07_plaskowski_wposzukiwaniu.pdf

8. Rokitno-Wolyn and Surroundings; Memorial Book and Testimony (Rokytne, Ukraine). (1967). Translation of Rokitno (Volin) ve-ha-seviva; sefer edut ve-zikaron. Edited by: E. Leoni. Tel Aviv.

9. Sbornik zakonov SSSR i Ukazov Prezidiuma Verxovnogo Soveta SSSR (1938 g. - noyabr' 1958 g.) [Collection of laws of the USSR and Decrees of the Presidium of the Supreme Soviet of the USSR (1938 - November 1958)] (1959). M.: Gosyurizdat, 710 s. (in Russian)

10. SSSR. Administrativno-territorial'noe delenie soyuznyx respublik na 1 yanvarya 1941 goda [THE USSR. Administrative-territorial division of the union republics on January 1, 1941] (1941). Inform.-stat. otd. pri Sekretariate Prezidiuma Verx. Soveta SSSR [Inform.-stat. dep. at the Secretariat of the Presidium Top. Council of the USSR], M.: Izd-vo Vedomostej Verxovnogo Soveta RSFSR, 1941. 490 s. (in Russian)

11. Tsentral'nyj derzhavnyj arkhiv hromads'kykh ob'iednan' Ukrainy [Central State Archives of Public Organizations of Ukraine]. F. 70. Op. 1. Spr. 1. 214 ark. 